\title{
SH2D1A Deficiency
}

National Cancer Institute

\section{Source}

National Cancer Institute. SH2D1A Deficiency. NCI Thesaurus. Code C126350.

A condition of decreased or absent presence or activity of $\mathrm{SH} 2$ domain protein $1 \mathrm{~A}$.

Deficiency of this protein is associated with X-linked lymphoproliferative syndrome 1

(Duncan Disease). 